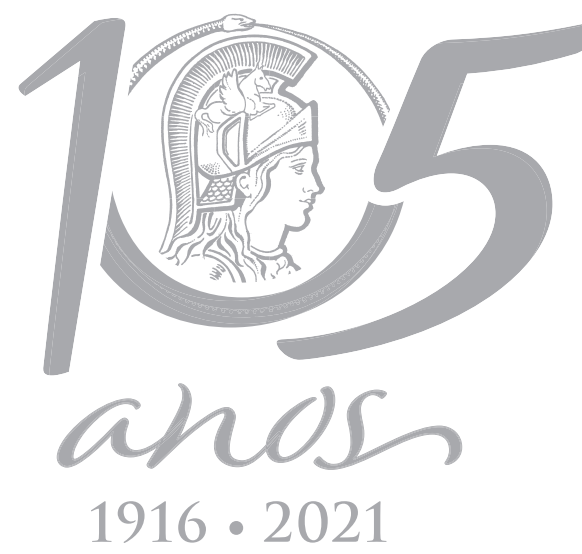

\title{
Plant growth-promoting mechanisms and genetic diversity of bacteria strains isolated from Brachiaria humidicola and Brachiaria decumbens
}

\author{
JOÃO T.C. OLIVEIRA, ARTHUR P.A. PEREIRA, ADIJAILTON J. SOUZA, GILKA T. SILVA, \\ WILLIANE P.S. DINIZ, EVERTHON F. FIGUEREDO, JÚLIA KUKLINSKY-SOBRAL \& \\ FERNANDO J. FREIRE
}

\begin{abstract}
Plant growth-promoting bacteria (PGPB) have received great interest in recent decades. However, PGPB mechanisms remain poorly understood in forage species. We aimed to evaluate roots endophytic and rhizospheric bacteria strains from Brachiaria humidicola and Brachiaria decumbens. The strains were evaluated for biological nitrogen-fixing in saline stress ( 0 to $10.0 \mathrm{~g} \mathrm{~L}^{-1}$ of $\mathrm{NaCl}$ ), $\mathrm{N}$-acyl homoserine lactones and indole-like compounds (ILC) production, the activity of hydrolytic enzymes, and inorganic phosphate solubilization (IPS) under different $C$ sources. The diversity of strains was assessed by BOX-PCR. About 58\% of strains were positive for BNF. High salinity levels reduced the growth and BNF. About 58\% produced N-acyl homoserine lactones. The ILC was present in $39 \%$ of strains. Cellulase, polygalacturonase, pectate lyase, and amylase production were observed in $77,14,22$, and $25 \%$ of strains, respectively. The IPS was observed in 44,81 , and $87 \%$ of isolates when glucose, mannitol and sucrose were used, respectively. Comparing two plant species and niches, the strains associated with $B$. humidicola and root endophytic presented more PGPB mechanisms than others. We found high strain diversity, of which $64 \%$ showed similarity lower than $70 \%$. These results can be supporting the bioproducts development to increase forage grasses production in tropical soils.
\end{abstract}

Key words: Bacteria-plant association, forage grasses, rhizosphere bacterial, root endophytic.

\section{INTRODUCTION}

The forage grasses have a primordial importance to worldwide livestock (Capstaff \& Miller 2018), mainly to Brazilian production chain because the meat and milk production is an almost exclusively pasture-based system (Cerri et al. 2016). In Brazil, there is a wide diversity of the tropical forage grasses which can be used as pasture (Aguiar et al. 2017).

The genus Brachiaria ssp. comprises about 114 million hectares of the pasture in Brazil.
Brachiaria decumbens (Stapf) R.D.Webster (signalgrass), B. brizantha (Stapf) Webster (palisadegrass), B. humidicola (Rendle) Morrone \& Zuloaga (koroniviagrass) and B. ruziziensis (R. Germain \& Evrard) Crins (ruzigrass) are the main pasture varieties present in the country (Rezende et al. 2017, Souza et al. 2018). The use of Brachiaria spp. grasses for pasture formation was possible due to their high adaptability and tolerance to different soil types and climatic conditions, as well as their easier and more 
flexible management (Euclides et al. 2010, Hungria et al. 2016, Souza et al. 2018).

Brazilian livestock sector has faced a strong challenge to become more productive and efficient, in addition to achieving sustainability throughout its production chain. In this scenario, there is a huge demand for low-cost technologies that can increase pasture production. An available alternative for this purpose is the use of plant growth-promoting bacteria (Aguirre et al. 2018, Araujo et al. 2012, Pedreira et al. 2017, Wemheuer et al. 2016). For example, the PGPB improve ecosystem services and contribute to increased primary production through biological nitrogen fixation (BNF), phytohormones and enzymes production, pest and disease control, increased plant tolerance and resistance to abiotic stresses such as drought and salinity (Andrade et al. 2018, Araújo et al. 2014, Oliveira et al. 2017, Wemheuer et al. 2016).

Bacteria can inhabit different niches such as soil, rhizosphere, phyllosphere, inside plant tissues (endophytic) and other. These different habitats contribute to a higher microbial diversity what has a huge potential to find biotechnology properties (Compant et al. 2010, Ferrara et al. 2012, Machado et al. 2013, Souza et al. 2017). Several benefits have been observed from the bacteria-plant association, such as increases in germination and seed emergence, plant growth and production and, consequently, soil healthy (Amaral et al. 2016, Hungria et al. 2016, Kim et al. 2012, Moreira et al. 2014).

The elucidation of the plant growth promoting potential related to bacteria associated these plants, as well as the knowledge of their genetic diversity, can generate biotechnological products (Araujo et al. 2012). It can represent an important alternative for improving the establishment and production of pasture fields. In addition, can contribute to reducing production costs, decreasing mineral fertilizers application and, consequently, mitigating the environmental impacts (Wemheuer et al. 2016).

However, the biotechnology potential of the bacterial associated with forage grasses remains poorly understood, mainly in tropical regions. In this context, the aim of this study was to evaluate 36 roots endophytic and rhizospheric bacterial isolates of the Brachiaria humidicola (Rendle.) Schweickerdt and Brachiaria decumbens Stapf for biotechnology properties related to plant growth promotion. For this, bacterial isolates were evaluated in vitro for their ability to perform nitrogen fixation in the different $\mathrm{NaCl}$ concentrations, $\mathrm{N}$-acyl homoserine lactones and ILC production, the activity of extracellular enzymes and inorganic phosphate $(P)$ solubilization trait under different carbon sources. Genetic diversity of bacterial isolates was assessed by BOX-PCR fingerprint technique.

\section{MATERIALS AND METHODS}

\section{Bacterial Isolates}

We evaluated a total 36 pure strains isolated from Brachiaria ssp. belongs to the Microbial Genetic and Biotechnology Laboratory, Unit Academic of Garanhuns, Federal University of Pernambuco, Brazil. The experiment consisted for 18 bacterial strains isolated from Brachiaria humidicola (Rendle) Schweickerdt and 18 bacterial isolated from Brachiaria decumbens Stapf, being nine root endophytic strains and nine rhizospheric strains per forage grass. All bacterial strains were removed from glycerol storage $\left(-20{ }^{\circ} \mathrm{C}\right.$ freezer) and re-cultured in TSA 10\% (Trypticase Soy Agar) culture medium (4.0 g TSA L ${ }^{-1} ; 10.0$ g agar $\mathrm{L}^{-1}$ ).

The analyzes were performed in triplicate and the EM303 (Pseudomonas oryzihabitans), belongs to the Microbial Genetic and Biotechnology Laboratory strain was used as a positive control. This bacterial isolated was 
obtained from soybean tissue and has potential to NBF, IAA (indole acetic acid) and lytic enzymes producer (Kuklinsky-Sobral et al. 2004).

\section{Biological nitrogen fixation test}

Biological nitrogen fixation test was performed according to methodology described by Döbereiner et al. (1995). For this, the isolates were inoculated in NFb semisolid culture media (5.0 g $\mathrm{L}^{-1}$ of malic acid; $0.5 \mathrm{~g} \mathrm{~L}^{-1}$ of $\mathrm{K}_{2} \mathrm{HPO}_{4} ; 0.2 \mathrm{~g} \mathrm{~L}^{-1}$ of $\mathrm{MgSO}_{4}$ $\mathrm{H}_{2} \mathrm{O} ; 0.1 \mathrm{~g} \mathrm{~L}^{-1}$ of $\mathrm{NaCl} ; 0.02 \mathrm{~g}$. $\mathrm{L}^{-1}$ of $\mathrm{CaCl}_{2} .2 \mathrm{H}_{2} \mathrm{O} ; 2.0 \mathrm{~mL}$ of micronutrient solution ( $0.4 \mathrm{~g} \mathrm{~L}^{-1}$ of CuSO $4 . \mathrm{H}_{2} \mathrm{O}$, $1.2 \mathrm{~g} \mathrm{~L}^{-1}$ of $\mathrm{ZnSO}_{4} \cdot \mathrm{H}_{2} \mathrm{O}, 1.4 \mathrm{~g} \mathrm{~L}^{-1}$ of $\mathrm{H}_{3} \mathrm{BO}_{3}, 1.0 \mathrm{~g} \mathrm{~L}^{-1}$ of $\mathrm{Na}_{2} \mathrm{MoO}_{4} \cdot 2 \mathrm{H}_{2} \mathrm{O}$, and $1.175 \mathrm{~g} \mathrm{~L}^{-1}$ of $\mathrm{MnSO}_{4} \cdot \mathrm{H}_{2} \mathrm{O}$ ); 2.0 $\mathrm{mL}$ of bromothymol blue solution; $4.0 \mathrm{ml}$ of $4 \mathrm{M}$ Fe EDTA; $1.0 \mathrm{~mL}$ of the vitamin solution $\left(0.1 \mathrm{~g} \mathrm{~L}^{-1}\right.$ of biotin; $0.02 \mathrm{~g} \mathrm{~L}^{-1}$ of pyridoxine); $4.5 \mathrm{~g} . \mathrm{L}^{-1}$ of $\mathrm{KOH} ; 1.8$ g. $L^{-1}$ of $A G A R ; p H=6.8$ ), free nitrogen source, and incubated at $28{ }^{\circ} \mathrm{C}$ for 8 days. Isolates positives to growth in NFb media were reinoculated in the same conditions. However, were added different $\mathrm{NaCl}$ concentrations into the culture media as follows: 0.1; 2.5; 5 and $10 \mathrm{~g} \mathrm{~L}^{-1}$ and same incubation condition were maintained. Bacterial growth was characterized by the formation of white halo near of the culture medium surface (Leite et al. 2018, Pereira et al. 2012).

\section{ALHs production (Quorum sensing potential activity)}

The characterization of quorum sensing signaling molecules was performed by the production of $\mathrm{N}$-acyl homoserine lactones (ALHs), using the Agrobacterium tumefaciens NTL4 (pZLR4) as reference which present the gene for the ALHS production. A. tumefaciens NTL4 was inoculated linearly in Petri dishes together with the evaluated bacterial strains. Perpendicularly to the same plate was added $10.0 \mu \mathrm{g} \mathrm{mL}^{-1}$ of Luria Bertani medium (LB-Agar) containing the X-gal chromogen (5-bromo-4-chloro-3-indolyl-betaD-galacto-pyranoside). Then the plates were incubated at $28{ }^{\circ} \mathrm{C}$ for $48 \mathrm{~h}$. The presence of the A. tumefaciens colonies with bluish color is indicative of the ALH production (Grönemeyer et al. 2012, Leite et al. 2014).

\section{Indole-like compounds (ILC) production}

Bacterial strains were evaluated for indole acetic acid (ILC) production. To order, the bacterial isolates were inoculated in liquid TSA medium, with and without L-tryptophan (5.0 $\mathrm{mM}$ ) addition. The strains were incubated under shaking at $120 \mathrm{rpm}$, at $28{ }^{\circ} \mathrm{C}$, in the absence of light, for $24 \mathrm{~h}$. Then, bacterial cultures were centrifuged at $12,000 \mathrm{~g}$ for $5 \mathrm{~min}$, after $1.5 \mathrm{~mL}$ of supernatant was transferred to clean microtube, and $0.5 \mathrm{~mL}$ of Salkowski reagent $\left(2.0 \% \mathrm{FeCl}_{3} 0.5\right.$ $M$ in $35.0 \%$ perchloric acid) was added. Samples were incubated in the dark room at $28{ }^{\circ} \mathrm{C}$ for 30 min (Crozier et al. 1988, Pereira et al. 2012). The ILC quantification was performed in a spectrophotometer at an optic density of 530 $\mathrm{nm}$.

\section{Lytic enzymes production}

The lytic enzymes production (cellulase, amylase, pectate lyase and polygalacturonase) was evaluated according to Stamford et al. (2001), Alves et al. (2002) and Carrim et al. (2006), respectively. In all enzymatic assays the incubations were performed at $28^{\circ} \mathrm{C}$ for $72 \mathrm{~h}$. The enzymatic activity was evaluated by the presence of bacterial growth halo in the culture medium. While the enzymatic index was determined by the ratio between diameter of the growth halo and the diameter of the bacterial colony.

\section{Inorganic phosphate solubilizing test}

The inorganic phosphate solubilizing test was performed according to Verma et al. (2001). The bacterial strains were inoculated in solid culture medium containing insoluble phosphate source (10 $\mathrm{g} \mathrm{L}^{-1}$ glucose, $5 \mathrm{~g} \mathrm{~L}^{-1} \mathrm{NH}_{4} \mathrm{Cl}, 1 \mathrm{~g} \mathrm{~L}^{-1} \mathrm{NaCl}, 1 \mathrm{~g} \mathrm{~L}^{-1}$ 
$\mathrm{MgSO}_{4} 7 \mathrm{H}_{2} \mathrm{O}, 4 \mathrm{~g} \mathrm{~L}^{-1} \mathrm{CaHPO}_{4}, 15 \mathrm{~g} \mathrm{~L}^{-1}$ agar, pH 7.2). Addition, the bacterial isolates that solubilized phosphate in the media containing glucose were also tested in others culture media, but using different $\mathrm{C}$ sources, such as sucrose and mannitol (10 $\left.\mathrm{g} \mathrm{L}^{-1}\right)$. Incubations occurred at $28^{\circ} \mathrm{C}$ for $72 \mathrm{~h}$. The inorganic phosphate solubilization index were estimated by the ratio between halo hydrolysis diameter and the bacterial colony diameter.

\section{Bacterial genetic variability}

The bacterial isolates genetic variability was analyzed by BOX-PCR fingerprint technique (Versalovic et al. 1994). For this, the isolates genomic DNA was extracted using the Genomic DNA Purification kit (Fermentas, Waltham, Massachusetts, EUA) according to the manufacturer's instructions. A PCR reaction was performed using the primer BOXA1R (5'-CTACGGCAAGGCGACGCTGACG-3), in a final volume of $25 \mu \mathrm{L}$ containing $10.0 \mathrm{ng}$ of the DNA template; $1.0 \mu \mathrm{M}$ of primer; $1.0 \mathrm{mM}$ of each dNTPS; $1 x$ of DMSO (dimetilsufoxamida); $1 x$ of Taq Buffer, $3.5 \mathrm{mM}$ of $\mathrm{MgCl}_{2}$ and $0.08 \mathrm{U}$ of Taq DNA polimerase (Fermentas, Fermentas, Waltham, Massachusetts, EUA).

Amplification reactions were performed with initial denaturation at $95{ }^{\circ} \mathrm{C}$ for $2 \mathrm{~min}$, 35 denaturation cycles at $9{ }^{\circ} \mathrm{C}$ for $2 \mathrm{~min}, 92$ ${ }^{\circ} \mathrm{C}$ for $30 \mathrm{~s}$, annealing at $50{ }^{\circ} \mathrm{C}$ for $1 \mathrm{~min}$ and extension at $65^{\circ} \mathrm{C}$ for $1 \mathrm{~min}$, followed by a final extension at $65^{\circ} \mathrm{C}$ for $10 \mathrm{~min}$. After amplification, the reactions were evaluated using agarose gel electrophoresis (1.5\%, v/v) in 1X TAE buffer (40.0 mM Tris-acetate, 1.0 mM EDTA) and stained with Blue green loading dye (LGC Bio, Cotia, São Paulo, Brazil). Agarose gel was photographed and analyzed using Gel Analyzer version 2010a.

\section{Statistical analysis}

The isolates groups (roots endophytic and rhizospheric) and qualitative variables were verified by the chi-square test $\left(X^{2}\right)$. Quantitative variables were analyzed by orthogonal contrast and statistical significance between contrast was verified by t-test. The comparison between the different $\mathrm{C}$ sources (sucrose and mannitol), used in the inorganic phosphate solubilization test, were evaluated by the Tukey test at the 5.0\% probability level, both using SISVAR 5.6 software.

Binary matrix of the DNA band profiles was used to verify the bacterial genetic variability. For this, a dendrogram was constructed based on Jaccard coefficient similarity and clusters were grouped using the UPGMA algorithm (Unweighted Pair-Group Method with Arithmetical Average), using PAST 2.15 software.

\section{RESULTS AND DISCUSSION}

The 36 bacterial isolates selected were positive for one or more plant growth-promoting (PGP) mechanisms (Table I). Bacterial growth in culture media without free nitrogen source was verified in $50 \%$ of the isolates. The increase of the salt concentration in the semisolid NFb media (0.1; 2.5; 5 and $10 \mathrm{~g} \mathrm{~L}^{-1}$ of $\mathrm{NaCl}$ ) affected bacterial growth and BNF capacity, with decreases in percentages of 100; $77 ; 55.5$ and $16 \%$, respectively. However, no significant differences were observed between isolates in the comparison between species, plant species and niches. In general rhizosphere bacteria showed higher salt tolerance in the culture medium than root endophytic isolates (Table I).

High levels of soluble salts may have toxic effects on microbial cells, decreasing bacterial activity, which may impact crucial ecosystem services provided by soil microorganisms, such 
Table I. In vitro PGP mechanisms of the 36 bacterial isolates associated with Brachiaria humidicola (Rendle.) Schweickerdt and Brachiaria decumbens Stapf. in the root and rhizospheric niche.

\begin{tabular}{|c|c|c|c|c|c|c|c|c|c|c|c|c|c|c|c|}
\hline \multirow{3}{*}{ Isolates ID } & \multicolumn{15}{|c|}{ Brachiaria humidicola (Rendle.) Schweickerdt (root) } \\
\hline & \multicolumn{5}{|c|}{$\mathrm{NFb}(\% \mathrm{NaCl})$} & \multirow{2}{*}{ ALHs } & \multicolumn{2}{|c|}{ IAA } & \multicolumn{4}{|c|}{ IE } & \multicolumn{3}{|c|}{ IS } \\
\hline & 0.0 & 0.1 & 2.5 & 5.0 & 10.0 & & CLT & SLT & CE & PO & PE & AM & GL & MA & SA \\
\hline UAGB1 & + & + & + & + & - & + & 35.52 & 5.47 & 0.00 & 0.00 & 4.26 & 1.81 & 3.83 & 1.36 & 1.66 \\
\hline UAGB2 & + & + & + & + & - & - & 0.00 & 0.00 & 0.00 & 0.00 & 0.00 & 0.00 & 3.28 & 2.19 & 1.60 \\
\hline UAGB3 & - & - & - & - & - & - & 0.00 & 0.00 & 0.93 & 0.00 & 0.00 & 0.00 & 0.00 & 0.00 & 0.00 \\
\hline UAGB4 & - & - & - & - & - & - & 29.53 & 0.00 & 1.19 & 0.00 & 0.00 & 0.00 & 0.00 & 0.00 & 0.00 \\
\hline UAGB5 & - & - & - & - & - & + & 0.00 & 0.00 & 0.91 & 0.00 & 0.00 & 0.00 & 0.00 & 0.00 & 0.00 \\
\hline UAGB6 & - & - & - & - & - & + & 26.38 & 2.40 & 1.20 & 0.68 & 2.20 & 1.20 & 1.59 & 2.74 & 1.67 \\
\hline UAGB7 & - & - & - & - & - & - & 63.04 & 5.03 & 1.08 & 0.00 & 0.00 & 0.00 & 4.26 & 3.64 & 6.54 \\
\hline UAGB8 & - & - & - & - & - & - & 38.11 & 14.78 & 1.00 & 0.00 & 0.00 & 0.00 & 3.08 & 3.64 & 3.29 \\
\hline \multirow[t]{2}{*}{ UAGB9 } & + & + & + & + & - & + & 30.05 & 5.25 & 1.00 & 0.00 & 0.00 & 0.00 & 3.14 & 4.66 & 4.32 \\
\hline & \multicolumn{15}{|c|}{ Brachiaria humidicola (Rendle.) Schweickerdt (rhizospheric) } \\
\hline UAGB10 & + & + & + & + & - & + & 13.48 & 9.21 & 1.20 & 0.00 & 4.86 & 1.09 & 0.00 & 0.00 & 0.00 \\
\hline UAGB11 & - & - & - & - & - & + & 0.00 & 0.00 & 0.91 & 0.96 & 3.36 & 1.49 & 2.80 & 0.00 & 0.00 \\
\hline UAGB12 & - & - & - & - & - & + & 0.00 & 0.00 & 1.30 & 0.00 & 3.43 & 1.48 & 0.00 & 0.00 & 0.00 \\
\hline UAGB13 & + & + & + & + & + & - & 16.07 & 2.79 & 0.96 & 0.94 & 0.00 & 0.00 & 0.00 & 0.00 & 0.00 \\
\hline UAGB14 & + & + & + & - & - & + & 0.00 & 0.00 & 0.97 & 0.00 & 0.00 & 1.49 & 0.00 & 0.00 & 0.00 \\
\hline UAGB15 & + & + & + & + & - & - & 0.00 & 0.00 & 1.05 & 0.00 & 0.00 & 0.00 & 0.00 & 0.00 & 0.00 \\
\hline UAGB16 & - & - & - & - & - & - & 0.00 & 0.00 & 1.10 & 0.00 & 0.00 & 2.62 & 0.00 & 0.00 & 0.00 \\
\hline UAGB17 & - & - & - & - & - & + & 0.00 & 0.00 & 1.12 & 0.00 & 0.00 & 1.92 & 0.00 & 0.00 & 0.00 \\
\hline \multirow[t]{2}{*}{ UAGB18 } & - & - & - & - & - & + & 0.00 & 0.00 & 1.06 & 0.00 & 2.54 & 1.20 & 2.16 & 2.11 & 2.12 \\
\hline & \multicolumn{15}{|c|}{ Brachiaria decumbens Stapf. (root) } \\
\hline UAGB19 & + & + & - & - & - & - & 0.00 & 0.00 & 1.18 & 0.00 & 0.00 & 0.00 & 2.31 & 3.30 & 3.47 \\
\hline UAGB20 & - & - & - & - & - & - & 0.00 & 0.00 & 0.00 & 0.00 & 0.00 & 0.00 & 1.40 & 4.00 & 4.50 \\
\hline UAGB21 & + & + & + & + & - & + & 0.00 & 0.00 & 1.24 & 0.64 & 0.00 & 0.00 & 2.58 & 4.00 & 5.38 \\
\hline UAGB22 & - & - & - & - & - & - & 64.72 & 10.94 & 0.95 & 0.00 & 0.00 & 0.00 & 5.00 & 0.00 & 0.00 \\
\hline UAGB23 & + & + & - & - & - & + & 0.00 & 0.00 & 1.16 & 0.00 & 0.00 & 0.00 & 0.00 & 0.00 & 0.00 \\
\hline UAGB24 & - & - & - & - & - & + & 0.00 & 0.00 & 0.00 & 0.00 & 0.00 & 0.00 & 0.00 & 0.00 & 0.00 \\
\hline UAGB25 & + & + & + & - & - & + & 0.00 & 0.00 & 0.00 & 0.00 & 8.27 & 0.00 & 0.00 & 0.00 & 0.00 \\
\hline UAGB26 & + & + & - & - & - & - & 0.00 & 0.00 & 0.78 & 0.63 & 7.55 & 0.00 & 0.00 & 0.00 & 0.00 \\
\hline \multirow[t]{2}{*}{ UAGB27 } & - & - & - & - & - & + & 0.00 & 0.00 & 1.09 & 0.00 & 0.00 & 0.00 & 0.00 & 0.00 & 0.00 \\
\hline & \multicolumn{15}{|c|}{ Brachiaria decumbens Stapf. (rhizospheric) } \\
\hline UAGB28 & - & - & - & - & - & + & 28.19 & 3.22 & 0.00 & 0.00 & 0.00 & 0.00 & 3.14 & 3.26 & 6.35 \\
\hline UAGB29 & + & + & - & - & - & + & 0.00 & 0.00 & 0.00 & 0.00 & 0.00 & 0.00 & 0.00 & 0.00 & 0.00 \\
\hline UAGB30 & + & + & + & + & - & + & 0.00 & 0.00 & 1.08 & 0.00 & 0.00 & 0.00 & 1.61 & 4.25 & 5.55 \\
\hline UAGB31 & - & - & - & - & - & + & 10.29 & 0.00 & 1.05 & 0.00 & 0.00 & 0.00 & 0.00 & 0.00 & 0.00 \\
\hline UAGB32 & - & - & - & - & - & - & 11.46 & 2.70 & 0.98 & 0.00 & 0.00 & 0.00 & 0.00 & 0.00 & 0.00 \\
\hline UAGB33 & + & + & + & - & - & + & 0.00 & 0.00 & 0.96 & 0.00 & 0.00 & 0.00 & 0.00 & 0.00 & 0.00 \\
\hline UAGB34 & + & + & + & + & + & - & 27.03 & 1.93 & 1.05 & 0.00 & 0.00 & 0.00 & 1.49 & 0.00 & 2.44 \\
\hline UAGB35 & + & + & + & - & - & + & 59.63 & 16.68 & 1.08 & 0.00 & 0.00 & 0.00 & 6.08 & 3.79 & 4.50 \\
\hline UAGB36 & + & + & + & + & + & - & 0.00 & 0.00 & 0.00 & 0.00 & 0.00 & 0.00 & 0.00 & 0.00 & 0.00 \\
\hline
\end{tabular}

$\mathrm{NFb}$ - culture media without N source (semisolid); ALHs - Quorum sensing production; IAA - Indole acetic acid production ( $\mu \mathrm{g} \mathrm{mL}^{-}$ 1); CTL - IAA production via L-Tryptophan-dependent; SLT - IAA production via L-Tryptophan-independent; IE - enzymatic index; CE - cellulase enzyme; PO - Polygalacturonase enzyme; PE - Pectate lyase enzyme; AM - Amylase enzyme; IS - P solubilization index; GL - Glucose source; MA - Mannitol source; SAC - Sucrose source. 
as biological nitrogen fixation (Egamberdieva \& Kucharova 2009).

Pereira et al. (2012) evaluated the effect of salinity on the PGP mechanisms of bacteria isolated from sugarcane plants. The authors reported that the bacterial strains were able to grow and produce indole acetic acid at a concentration of up to $10 \mathrm{~g} \mathrm{~L}^{-1} \mathrm{NaCl}$ in the culture media. However, the growth rate was reduced and BNF was completely inhibited at 25 and 50 $\mathrm{g} \mathrm{L}^{-1} \mathrm{NaCl}$ concentrations. In general rhizosphere bacteria have a higher capacity to fix nitrogen in high salt concentrations of endophytic bacteria. This is because rhizosphere isolates have greater ability to adapt to environmental changes (Ferrara et al. 2012, Richardson et al. 2009, Santos et al. 2012).

ALHs and quorum sensing production were detected in $58 \%$ of the bacterial isolates, no distinction between plant species and niches was verified (Table I). The ALHs production, auto-inducers and chemical signal chemical are related to the ability of intercellular communication, mobility regulation, horizontal gene transfer, enzyme production, biofilm formation and stress tolerance (Pinton et al. 2010).

The biofilms provide protection to microbial populations againstenvironmental stresses, such as drought and salinity. Ability to form biofilm is a desired feature in bacterial strains intended for inoculant composition. Biofilms have helped to maintain the inoculum population in the soil or seed, but the bacteria-plant interaction may be beneficial or deleterious (Grönemeyer et al. 2012).

Indole-like compounds biosynthesis was identified in 39\% of bacterial strains. This phytohormone was detected in the concentration ranging from 10 to $65 \mu \mathrm{g} \mathrm{mL}$ 1. The ILC production by metabolic pathway L-tryptophan-independent was observed in the
$86 \%$ of isolates, however ILC concentration was lower and ranged from 2 to $16.5 \mu \mathrm{g} \mathrm{mL}^{-1}$ (Table I).

Bacteria associated with plants can produce ILC by different pathways. The more known route in PGPBs for indole-like molecules synthesis is the via IPyA (indole pyruvic acid) in which the bacteria use the amino acid L-tryptophan as a precursor.

However, some bacterial can synthesize ILC by L-tryptophan-independent metabolic routes, however the production rate is lower (Richardson et al. 2009). Auxins synthesis by microorganisms associated with plants promotes root growth and root elongation, consequently, increasing the absorption of water and nutrients and thus potentiating the development of plants (Araujo et al. 2012, Machado et al. 2013).

Enzymatic production was observed in 78 , 14,22 and $25 \%$ of the bacterial strains for the enzymes cellulase, polygalacturonase, pectate lyase and amylase, with enzymatic indexes of 1.3, 1.8, 8.3 and 2.7, respectively (Table I).

The lytic enzymes produced by bacteria act in the degradation of several organic compounds and have great potential of application in the production of tissues, food and paper, besides use in agriculture. In the latter case, lytic enzyme-producing bacterial strains can more easily colonize the plant and act through its PGP mechanism (Compant et al. 2010).

Inorganic phosphate solubilizing (IPS) was observed in $44 \%$ of isolates in the culture medium containing glucose as carbon source. In the culture media containing mannitol and sucrose, $81 \%$ and $87.5 \%$ of the bacterial strains were positive for the IPS test. The highest solubilization rates were $6.1,4.7$ and 6.5 , in the glucose, mannitol and sucrose respectively (Table I). Some microorganisms present in soils and/or associated with plants play an important role in the phosphorus cycling, hydrolyzing $P$ inorganic forms, making it susceptible of 
assimilation by the plants, from the action of hydrolytic enzymes, mainly acid phosphatases (Leite et al. 2014, Santos et al. 2012, Verma et al. 2001).

The inorganic phosphate solubilizing in vitro by bacteria can occur in media containing different carbon sources and supplemented with insoluble phosphate forms. In this work, it was observed that the ability to solubilize inorganic phosphate was dependent on the carbon source added to the culture medium.

Barroso et al. (2006) reported greater effect of carbon source on the inorganic phosphate solubilization in vitro by Aspergillus niger. The maltose, sucrose, glucose, mannose and fructose were the carbon sources which most stimulated citric acid production, consequently, increasing the IPS in the culture media. In this work, sucrose was the carbon source that most promoted inorganic phosphate solubilization (Table II).

A high heterogeneity of PGP mechanisms was observed, when evaluated according to the plant species and niche (Table III). Analysis of orthogonal contrasts showed that B. humidicola bacterial isolates had higher potential for PGP mechanism expression than $B$. decumbens isolates. The root endophytic isolates synthesized higher ILC concentrations in the presence of L-tryptophan and had the highest phosphate solubilization index in media containing glucose and mannitol as carbon source. While the rhizosphere isolates were distinguished in the enzymatic synthesis of cellulase and amylase, and in the solubilization of phosphate (Table III).

Considering the forage grass species, the root bacterial isolates of $B$. humidicola produced higher ILC L-tryptophan-dependent concentrations and presented greater ability to perform phosphate solubilization at different carbon sources. While the rhizosphere bacterial isolates had the highest enzymatic indexes for all enzymes evaluated.

For niches, the rhizosphere isolates of $B$. decumbens showed highest ILC concentrations by L-tryptophan pathway and the solubilization of phosphate, mainly in sucrose as carbon source in the culture media. The roots isolates also presented highest enzymatic indices for polygalacturanase and pectate lyase enzymes (Table III).

Endophytic niches, such as root and rhizosphere are physically, chemically and biologically distinct. In the rhizosphere there is action of the root exudates, which modify the nutritional quality of the niche, in comparison with the bulk soil. In this niche there is a greater competition between different genera and species of microorganisms (Compant et al. 2010, Machado et al. 2013, Souza et al. 2017). In contrast, the root endophytic niche is more stable and uniform, with less competition between microorganisms and greater availability of nutrients. In this way, bacteria from distinct niches present different mechanisms to promote plant growth according to their adaptive capacity, directly reflecting their potential to influence the

Table II. Average of inorganic phosphate solubilization index, in vitro, with different $\mathrm{C}$ sources in the culture media (glucose, mannitol and sucrose). Isolates associated with Brachiaria humidicola (Rendle.) Schweickerdt and Brachiaria decumbens Stapf. from root and rhizosphere niche.

\begin{tabular}{|c|c|c|c|}
\hline Carbon source & Glucose & Mannitol & Sucrose \\
\hline Solubilization index (average) & 2.98 C & $3.30 \mathrm{~B}$ & $3.81 \mathrm{~A}$ \\
\hline Number of positive isolates & 16 & 13 & 14 \\
\hline
\end{tabular}

Means followed by the same letter do not differ by Tukey test at $5 \%$ probability. 
Table III. Comparison between groups of averages by orthogonal contrasts for the PGP mechanisms of 36 bacterial isolates associated with Brachiaria humidicola (Rendle.) Schweickerdt and Brachiaria decumbens Stapf. in endophytic root (ER) and rhizosphere (RI) niches.

\begin{tabular}{|c|c|c|c|c|c|c|c|c|c|}
\hline \multirow{2}{*}{ Average } & \multicolumn{2}{|c|}{ IAA } & \multicolumn{4}{|c|}{ IE } & \multicolumn{3}{|c|}{ IS } \\
\hline & CLT & SLT & CE & PO & PE & AM & GL & MA & SA \\
\hline B. humidicola & 14.01 & 5.31 & 0.94 & 0.14 & 1.15 & 0.80 & 1.34 & 2.54 & 2.65 \\
\hline B. decumbens & 11.18 & 5.91 & 0.70 & 0.07 & 0.88 & 0.00 & 1.31 & 2.83 & 4.02 \\
\hline Nicho ER & 15.96 & 5.92 & 0.76 & 0.11 & 1.24 & 0.17 & 1.69 & 2.95 & 3.24 \\
\hline Nicho RIZ & 9.23 & 5.22 & 0.88 & 0.11 & 0.79 & 0.63 & 0.96 & 2.24 & 3.49 \\
\hline B. humidicola - ER & 24.74 & 5.08 & 0.81 & 0.08 & 0.72 & 0.34 & 2.13 & 3.04 & 3.18 \\
\hline B. humidicola - RIZ & 3.28 & 6.00 & 1.08 & 0.21 & 1.58 & 1.26 & 0.55 & 1.06 & 1.06 \\
\hline B. decumbens - ER & 7.19 & 10.94 & 0.71 & 0.14 & 1.76 & 0.00 & 1.25 & 2.83 & 3.34 \\
\hline B. decumbens - RIZ & 15.18 & 4.90 & 0.69 & 0.00 & 0.00 & 0.00 & 1.37 & 2.83 & 4.71 \\
\hline Total & 12.60 & 5.57 & 0.82 & 0.11 & 1.01 & 0.40 & 1.33 & 2.68 & 3.34 \\
\hline \multicolumn{10}{|c|}{ Brachiaria humidicola (Rendle.) Schweickerdt vs Brachiaria decumbens Stapf } \\
\hline T test & $2.49^{*}$ & $-0.23^{\text {ns }}$ & $9.02^{* \star}$ & $7.93^{\star *}$ & $0.9^{\mathrm{ns}}$ & $39.21^{\star *}$ & $0.34^{\mathrm{ns}}$ & $-1.58^{\text {ns }}$ & $-13.45^{\star *}$ \\
\hline \multicolumn{10}{|c|}{ Root vs Rhizospheric } \\
\hline T test & $5.95^{\star *}$ & $0.28^{\mathrm{ns}}$ & $-4.47^{\star \star}$ & $0.32^{\text {ns }}$ & $1.53^{\mathrm{ns}}$ & $-22.71^{* *}$ & $8.37^{\star *}$ & $3.90^{* *}$ & $-2.38^{*}$ \\
\hline \multicolumn{10}{|c|}{ Brachiaria humidicola (Rendle.) Schweickerdt - Root vs Rhizospheric } \\
\hline T test & $16.17^{\star *}$ & $-0.27^{n s}$ & $-10.03^{* *}$ & $-11.72^{* *}$ & $-6.52^{\star \star}$ & $-22.67^{* *}$ & $12.94^{* *}$ & $9.38^{* *}$ & $24.00^{* *}$ \\
\hline \multicolumn{10}{|c|}{ Brachiaria decumbens Stapf - Root vs Rhizospheric } \\
\hline T test & $-4.35^{\star *}$ & $1.04^{\mathrm{ns}}$ & $0.42^{\mathrm{ns}}$ & $10.15^{\star *}$ & $3.09^{* *}$ & $0.0^{\mathrm{ns}}$ & $-0.91^{\mathrm{ns}}$ & $0.00^{\mathrm{ns}}$ & $-7.24^{\star *}$ \\
\hline
\end{tabular}

IAA - Indole acetic acid production ( $\mu \mathrm{g} \mathrm{mL}^{-1}$ ); CTL - IAA production via L-Tryptophan-dependent; SLT - IAA production via L-Tryptophan-independent; IE - enzymatic index; CE - cellulase enzyme; PO - Polygalacturonase enzyme; PE - Pectate lyase enzyme; AM - Amylase enzyme; IS - P solubilization index; GL - Glucose source; MA - Mannitol source; SAC - Sucrose source; ${ }^{\text {ns }}$ no significant; * and ** - significant at $5 \%$ and $1 \%$ of probability by the $t$ test.

plant development and growth over the natural environment (Compant et al. 2010, Ferrara et al. 2012).

The BOX-PCR technique evidenced that $64 \%$ of bacterial isolates had genetic similarity of less than $70 \%$ (Figure 1). However, UAGB5 and UAGB6, UAGB8 and UAGB9 root endophytes and UAGB 12 and UAGB 14 isolates from the rhizosphere of $B$. humidicola presented high similarity to each other, reaching $100 \%$ in both evaluated niches (Figure 1).

The microbial diversity in the plants is influenced by the differences in the quantity and chemical composition of the root exudates, which can be modified by the genotype, phenological and nutritional plant state, among other (Murphy et al. 2016, Oliveira et al. 2017). Despite the distinction between niches, there are microorganisms able to migrate between them, adapting the conditions of each niche, having as the main causes of migration the environmental conditions and nutritional status of plants (Luvizotto et al. 2010).

The positive effects of inoculating bacteria with PGP mechanisms in non-leguminous plants may be numerous (Hungria et al. 2016, Lima et al. 2018). These effects may occur by direct influence with the production of plant growth regulators (phytohormones) and the solubilization of inorganic phosphate, or by 


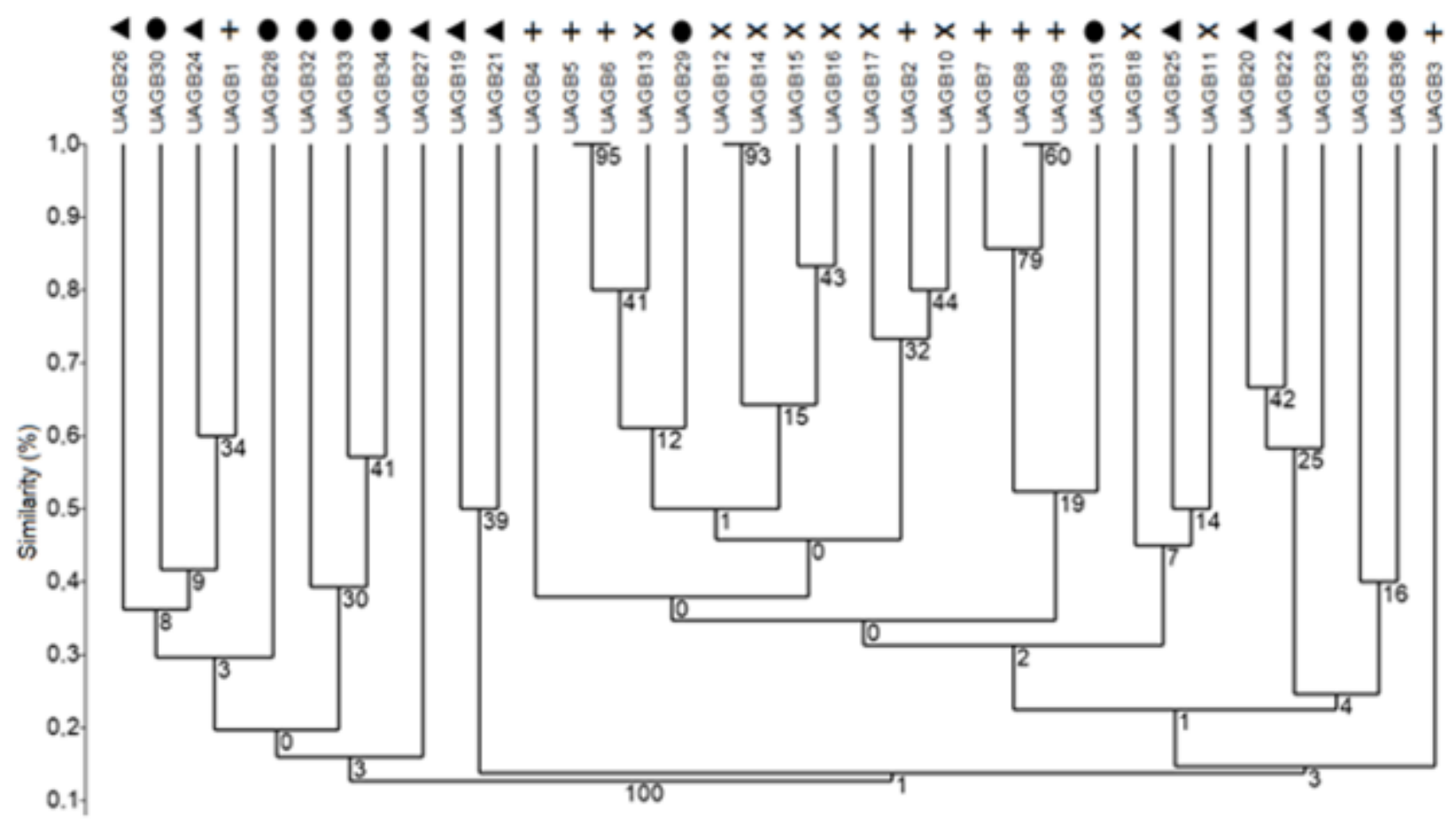

Figure 1. Dendrogram of genetic similarity using BOX gene based on the Jaccard Coefficient and grouped by the algorithm Unweighted Pair-Group Method with Arithmetical Average (UPGMA) of the 36 isolates associated with Brachiaria humidicola (Rendle.) Schweickerdt and Brachiaria decumbens Stapf. from root and rhizospheric niche. + $=$ root niche isolates of $B$. humidicola; $x=$ rhizospheric niche isolates of $B$. humidicola; $\boldsymbol{A}=\operatorname{root}$ niche isolates of $B$. decumbens; $\bullet$ = rhizospheric niche isolates of $B$. decumbens.

indirect influence, such as the suppression of pathogens by production of siderophores or antibiotics (Andreote et al. 2014).

The inoculation of Burkholderia phytofirmans, a bacterial strain with PGP mechanisms in seeds of Panicum virgatum (Alamo cultivar) was able to increase seed germination speed index, as well as root length by $33 \%$ and shoot length by $35.6 \%$ after 30 days of emergency (Kim et al. 2012). Inoculation of B. brizantha with diazotrophic bacteria of genus Bacillus spp. showed an increase in forage mass, leaf area, leaf green intensity, leaf number and tillers in the average of the three cuts (Araujo et al. 2012)

The knowledge of the biotechnological potential of bacteria associated to forage grasses in different colonization niches aims at the development of inoculant, able to reduce the use of fertilizers, as well as to promote the vegetal growth, thus increasing the forage production (Araújo et al. 2014, Hungria et al. 2016, Machado et al. 2013).

\section{CONCLUSION}

All bacterial isolates were positive for one or more PGP mechanisms, regardless of grass species or niche. The bacterial isolates were able to fix nitrogen at high salt concentrations, besides producing ALH molecule and ILC with and without L-tryptophan, and synthesize extracellular enzymes (cellulase, polygalacturonase, pectate lyase and amylase). Carbon source has strong effect on inorganic phosphate solubilization in vitro. Bacterial isolates from B. humidicola (Rendle.) Schweickerdt showed higher number of biotechnological characteristics. High 
genetic diversity was observed, with $64 \%$ of the isolates below $70 \%$ of similarity, without the formation of similar clusters by plant species and colonization niche. Considering the PGP mechanisms, the strains with the highest potential for inoculant formulation were: UAGB1UAGB6-UAGB9-UAGB10-UAGB21-UAGB34-UAGB35 (10-12 PGP mechanisms). The knowledge of the biotechnological potential and genetic diversity of bacteria associated with forage grasses becomes an important tool for the development of bioproducts, being an alternative for pasture management and yield, as well as reducing costs and environmental impacts.

\section{REFERENCES}

AGUIAR AR ET AL. 2017. Gastrointestinal nematode larvae in dairy cattle bred on Panicum maximum cv. Mombasa, Cynodon, Brachiaria mutica and Brachiaria decumbens pastures. J Anim Plant Sci 31: 5074-5078.

AGUIRRE PF, OLIVO CJ, RODRIGUES PF, FALK DR, ADAMS CB \& SCHIAFINO HP. 2018. Forage yield of Coastcross-1 pastures inoculated with Azospirillum brasilense. Acta Sci 40: 2-8.

ALVES MH, CAMPOS-TAKAKI GM, PORTO ALF \& MILANIZ AI. 2002. Screening of Mucor spp. for the production of amylase, lipase, and protease. Braz J Microbiol 33: 225-230.

AMARAL FP, PANKIEVICZ VCS, ARISI ACM, SOUZA EM, PEDROSA F \& STACEY G. 2016. Differencial growth responses of Brachypodium distachyon genotypes to inoculation with plant growth promoting rhizobacteria. Plant Mol Biol 90: 689-697.

ANDRADE PAM, DIAS ACF, COTTA SR, OLIVEIRA JTC, OLIVEIRA JFP, FREIRE FJ, ANDREOTE FD \& KUKLINSKY-SOBRAL J. 2018. Differential niche occupation and the biotechnological potential of Methylobacterium species associated with sugarcane plants. Afr J Microbiol Res 12: 595-605.

ANDREOTE FA, GUMIERE T \& DURRER A. 2014. Exploring interactions of plant microbiomes. Sci Agric 71: 528-539.

ARAÚJO EO, MARTINS MR, MERCANTE FM, VITORINO ACT \& URQUIAGA SS. 2014. Herbaspirillum seropedicae inoculation and nitrogen fertilization on nitrogen use efficiency of different corn genotypes. Afr J Agric 9: 3025-3031.
ARAUJO FF, GUABERTO LM \& SILVA IF 2012. Bioprospecção de rizobactérias promotoras de crescimento em Brachiaria brizantha. R Bras Zootec 41: 521-527.

BARROSO CB, PEREIRA GT \& NAHAS E. 2006. Solubilization of $\mathrm{CaHPO}_{4}$ and $\mathrm{AlPO}_{4}$ by Aspergillus niger in culture media with different carbon and nitrogen sources. Braz J Microbiol 37: 434-438.

CAPSTAFF NMC \& MILLER AJ. 2018. Improving the yield and nutritional quality of forage crops. Front Plant Sci 9: 1-18.

CARRIM AJJI, BARBOSA EC \& VIEIRA JDG. 2006. Enzymatic activity of endophytic bacterial isolates of Jacaranda decurrens Cham. (Carobinha-do-campo). Braz Arch Biol Technol 49: 353-359.

CERRI CC, MOREIRA CS, ALVES PA, RAUCCI GS, CASTIGIONI BA, MELLO FFC \& CERRI DGP. 2016. Assessing the carbon footprint of beef cattle in Brazil: a case study with 22 farms in the State of Mato Grosso. J Clean Prod 121: 198-199.

COMPANT S, CLÉMENT C \& SESSITSCH A. 2010. Plant growthpromoting bacteria in the rhizo-and endosphere of plant: Their role, colonization, mechanisms involved and prospects for utilization. Soil Biol Biochem 42: 669-678.

CROZIER A, ARRUDA P, JASMIM JM, MONTEIRO AM \& SANDBERG G. 1988. Analysis of indole-3-acetic acid and related indoles in culture medium from Azospirillum lipoferum and Azospirillum brasiliense. Appl Microbiol Biot 54: 2833-2837.

DÖBEREINER J, BALDANI VLD \& BALDANI JI. 1995. Como isolar e identificar bactérias diazotróficas de plantas nãoleguminosas, 1ạ ed., Brasília: Embrapa Agrobiologia, 60 p.

EGAMBERDIEVA D \& KACHAROVA Z. 2009. Selection for root colonizing bacteria stimulating wheat growth in saline soils. Biol Fert Soils 45: 563-571.

EUCLIDES VPB, VALLE CB, MACEDO MCM, ALMEIDA RG, MONTAGNER DB \& BARBIOSA RA. 2010. Brazilian scientific progress in pasture research during the first decade of $X X I$ century. R Bras Zootec 39: 151-168.

FERRARA FIS, OLIVEIRA ZMO, GONZALES HHS, FLOH EIS \& BARBOSA HR. 2012. Endophytic and rhizospheric enterobacteria isolated from sugar cane have different potentials for producing plant growth-promoting substances. Plant Soil 353: 409-417.

GRÖNEMEYER JL, BURBANO GS, HUREK T \& REINHOLD-HUREK B. 2012. Isolation and characterization of root-associated bacteria from agricultural crops in the Kavango region of Namibia. Plant Soil 356: 67-82. 
HUNGRIA M, NOGUEIRA MA \& ARAUJO RS. 2016. Inoculation of Brachiaria spp. with the plant growthpromoting bacterium Azospirillum brasilense: An environmentfriendly component in the reclamation of degraded pastures in the tropics. Agr Ecosys Environ 221: 125-131.

KIM S, LOWMAN S, HOU G, NOWAK J, FLINN B \& MEI C. 2012. Growth promotion and colonization of switchgrass (Panicum virgatum) cv. Alamo by bacterial endophyte Burkholderia phytofirmans strain PSJN. Biotechnol Biofuels 5: 2-10.

KUKLINSKY-SOBRAL J, ARAÚJO WL, MENDES R, GERALDI IO, PIZZIRANI-KLEINER AA \& AZEVEDO JL. 2004. Isolation and characterization of soybean associated bacteria and their potential for plant growth promotion. Environ Microbiol 6: 1244-1251.

LEITE MCBS, FARIAS ARB, FREIRE FJ, ANDREOTE FD, KUKLINSKYSOBRAL J \& FREIRE MBGS. 2014. Isolation, bioprospecting and diversity of salt-tolerant bacteria associated with sugarcane in soils of Pernambuco, Brazil. Rev Bras Eng Agric Ambient 18: 73-79.

LEITE MCBS, PEREIRA APA, SOUZA AJ, ANDREOTE FD, FREIRE FJ \& KUKLINSKY-SOBRAL J. 2018. Bioprospection and genetic diversity of endophytic bacteria associated with cassava plant. Rev Caatinga 31: 315-325.

LIMA DRM, SANTOS IBS, OLIVEIRA JTC, BARBOSA JG, DINIZ WP, FARIAS ARB, FREIRE FJ \& KUKLINSKY-SOBRAL J. 2018. Tolerance of potentially diazotrophic bactéria to adverse environmental conditions and plant growth-promotion in sugarcane. Arch Agron Soil Sci 1: 1534-1548.

LUVIZOTTO DM, MARCON J, ANDREITE FD, DINI-ANDREOTE F \& NEVES AAC. 2010. Genetic diversity and plant-growth related features of Burkholderia spp. from sugarcane roots. World J Microbiol Biotechnol 26: 1829-1836.

MACHADO RG, SÁ ELS, BRUXEL M, GIONGO A, SANTOS NS \& NUNES AS. 2013. Indoleacetic acid producing rhizobia promote growth of Tanzania grass (Panicum maximum) and Pensacola grass (Paspalum saurae). Int J Agric Biol 15: $827-834$.

MOREIRA CDA, PEREIRA DH, COIMBRA RA \& MOREIRA IDA. 2014. Germinação de gramíneas forrageiras em função da inoculação de bactérias diazotróficas. Sci Elec Arch 6: 90-96.

MURPHY CA, FOSTER BL \& GAO C. 2016. Temporal dynamics in rhizosphere bacterial communities os three perennial grassland species. Agronomy 6: 1-17.

OLIVEIRA JTC, FIGUEREDO EF, DINIZ WPS, OLIVEIRA LFP, ANDRADE PA, ANDREOTE FD, KUKLINSKY-SOBRAL J, LIMA DR \& FREIRE FJ.
2017. Diazotrophic bacterial community of degraded pastures. Appl Environ Soil Sci 2017: 1-10.

PEDREIRA BC, BARBOSA PL, PEREIRA LET, MOMBACH MA, DOMICIANO LF, PEREIRA DH \& FERREIRA A. 2017. Tiller desity and tillering on Brachiaria brizantha cV. Marandu pastures inoculated with Azospirillum brasilense. Arq Bras Med Veterinario Zootec 69: 1039-1046.

PEREIRA APA, SILVA MCB, OLIVEIRA JRS, RAMOS APS, FREIRE MBGS, FREIRE FJ \& KUKLINSKY-SOBRAL J. 2012. Influência da salinidade sobre o crescimento e a produção de ácido indol acético de Burkholderia spp. endofíticas de canade-açúcar. Biosci J 28: 112-121.

PINTON R, DIAS A, XAVIER TF, ROUWS LFM, XAVIER GR, RUMJANEK NG \& RIBEIRO RLD. 2010. Caracterização morfocultural, biossintese de autoindutor e formação de biofilme por rizobactérias de hortaliças. Pesq Agropec Bras 45: 284-293.

REZENDE CP, MACEDO TM, PEREIRA JM, BELLOMI RM, CARVALHO GGP, TOSTO MSL, CIRME LGA \& MARANHÃO CMA. 2017. BiomaSS turnover in Brachiaria cultivars in a tropical environment. Biosci J 33: 644-651.

RICHARDSON AE, BAREA JM, MCNEILL AM \& PRIGENT-COMBARET C. 2009. Acquisition of phosphorus and nitrogen in the rhizosphere and plant growth promotion by microorganisms. Plant Soil 321: 305-339.

SANTOS IB, LIMA DRM, BARBOSA JG, OLIVEIRA JTC, FREIRE FJ \& KUKLINSKY-SOBRAL J. 2012. Bactérias diazotróficas associadas a raízes de cana-de-açúcar: solubilização de fosfato inorgânico e tolerância a salinidade. Biosci J 28: 142-149.

SOUZA JS, CHIARI L, SIMEÃO RM, VILELA MM \& SALGADO LR. 2018. Development, validation and characterization of genic microsatellite markers in Urochloa species. Am J Plant Sci 9: 281-295.

SOUZA ST, BAURA VA, SANTOS SA, FERNANDES-JÚNIOR PI, REIS JUNIOR FB, MARQUES MR, PAGGI CM \& BRASIL MS. 2017. Azospirillum spp. from native forage grasses in Brazilian Pantanal floodplain: biodiversity and plant growth promotion potential. World J Microb Biot 33: 1-13.

STAMFORD NP, COELHO LC \& ARAUJO JM. 2001. Production and characterization of a thermostable alpha-amylase from Nocardiopsis sp. endophyte of yam bean. Bioresource Technol 76: 137-141.

VERMA SC, LADHA JK \& TRIPATHI AK. 2001. Evalution of plant growth promoting and colonization ability of endophytic diazotrophs from deep water rice. J Biotec 91: 127-141.

VERSALOVIC J, SCHNEIDER M, BRUIJN FJ \& LUPSKI J. 1994. Genomic fingerprinting of bacteria using repetitive 
sequence-based polymerase chain reaction. Methods Mol Cell Biol 5: 25-40.

WEMHEUER F, KAISER K, KARLOVSKY P, DANIEL R, VIDAL S \& WEMHEUER B. 2016. Impact of grassland management regimes on bacterial endophyte diversity differs with grass species. Lett Appl Microbiol 62: 323-329.

\section{How to cite}

OLIVEIRA JTC, PEREIRA APA, SOUZA AJ, SILVA GT, DINIZ WPS, FIGUEREDO EF, KUKLINSKY-SOBRAL J \& FREIRE FJ. 2021. Plant growth-promoting mechanisms and genetic diversity of bacteria strains isolated from Brachiaria humidicola and Brachiaria decumbens. An Acad Bras Cienc 93: e20191123. DOI 10.1590/0001-3765202120191123.

Manuscript received on September 17, 2019;

accepted for publication on December 16, 2019

\section{JOÃO T.C. OLIVEIRA ${ }^{1}$}

https://orcid.org/0000-0001-7469-5106

ARTHUR P.A. PEREIRA ${ }^{2}$

https://orcid.org/0000-0001-9402-3243

ADIJAILTON J. SOUZA ${ }^{3}$

https://orcid.org/0000-0001-6578-4414

\section{GILKA T. SILVA ${ }^{4}$}

https://orcid.org/0000-0002-3681-7309

\section{WILLIANE P.S. DINIZ}

https://orcid.org/0000-0002-5596-5534

EVERTHON F. FIGUEREDO 3

https://orcid.org/0000-0002-9252-4930

\section{JÚLIA KUKLINSKYY-SOBRAL ${ }^{1}$}

https://orcid.org/0000-0002-4955-347X

\section{FERNANDO J. FREIRE 4}

https://orcid.org/0000-0002-3264-712X

${ }^{1}$ Universidade Federal do Agreste de Pernambuco, Avenida Bom Pastor, s/n, Boa Vista, 55293-270 Garanhuns, PE, Brazil

${ }^{2}$ Universidade Federal do Ceará, Departamento de Ciências do Solo, Avenida da Universidade, 2853, Benfica, 60020-181 Fortaleza, CE, Brazil

${ }^{3}$ Escola Superior de Agricultura Luiz de Queiroz, Universidade de São Paulo, Avenida Pádua Dias, 235, Agronomia, 13418-900 Piracicaba, SP, Brazil

${ }^{4}$ Universidade Federal Rural de Pernambuco, Rua Dom Manuel de Medeiros, s/n, Dois Irmãos, 52171-900 Recife, PE, Brazil

Correspondence to: João Tiago Correia Oliveira

E-mail:oliveirajtc@gmail.com

\section{Author contributions}

Substantial contribution to conception and design: JTCO, APAP, AJS, JKS, FJF. Substantial contribution to acquisition of data: JTCO, GTS, WPSD, EFF, JKS, FJF. Substantial contribution to analysis and interpretation of data: JTCO, APAP, AJS, JKS. Critically revising the article for important intellectual content: JTCO, APAP, AJS, JKS. All authors draft the article and approve the final version to be published.

\section{(cc) BY}

